\title{
Evaluation of Concrete Durability Performance with Sodium Silicate Impregnants
}

\author{
Sang-Soon Park, ${ }^{1}$ Yun Yong Kim, ${ }^{2}$ Byung Jae Lee, ${ }^{2}$ and Seung-Jun Kwon ${ }^{3}$ \\ ${ }^{1}$ Department of Civil Engineering, Sangmyung University, 31 Sangmyung-ro, Dongnam-gu, Cheonan 330-720, Republic of Korea \\ ${ }^{2}$ Department of Civil Engineering, Chungnam National University, 99 Daehak-ro, Yuseong-gu, Daejeon 305-764, Republic of Korea \\ ${ }^{3}$ Department of Civil and Environmental Engineering, Hannam University, 133 Ojeong-dong, Daedeok-gu, \\ Daejeon 306-791, Republic of Korea
}

Correspondence should be addressed to Seung-Jun Kwon; jjuni98@hannam.ac.kr

Received 23 April 2014; Revised 24 July 2014; Accepted 26 July 2014; Published 21 August 2014

Academic Editor: Tao Zhang

Copyright (c) 2014 Sang-Soon Park et al. This is an open access article distributed under the Creative Commons Attribution License, which permits unrestricted use, distribution, and reproduction in any medium, provided the original work is properly cited.

\begin{abstract}
This paper presents an enhanced performance in concrete impregnated with silicate compound. Two different types of impregnant materials (inorganic and combined type) are applied to concrete samples with different strength grade (21 MPa and $34 \mathrm{MPa}$ ). Through lab-scale test, improved performances in impregnated concrete are evaluated regarding porosity, strength, chloride diffusion coefficient, permeability of air/water, and absorption. Long-term exposure tests including strength, chloride penetration depth and contents, and electrical potential for steel corrosion are performed for different marine conditions. While the surfaceimpregnated concrete shows marginal increase in strength, significant improvements of porosity, absorption, and permeability are evaluated. The resistance to chloride attack reasonably improved through simply spraying the inorganic silicate in atmospheric-salt spraying condition.
\end{abstract}

\section{Introduction}

Reinforced concrete (RC) structures usually undergo deteriorations and the damages due to deteriorations eventually cause the structural safety problems although they have been used showing good structural and durability performance. Recently, repair techniques using surface-impregnation are proposed for improvement of concrete properties [1-4]. The research significance of surface-impregnated concrete can be explained in two viewpoints. One is a development of reactive repair material using silicate compound. In 1980-90, impregnation with sulfate compound was used for improvement of strength and elasticity of concrete. However, the repair technique using additional formation of ettringite due to sulfate compound had a limited application to concrete structures because another hydration procedure or high temperature was required for the impregnation [4]. Afterwards, liquid organic or inorganic/organic surface impregnants using silicate compound were developed and applied to existing RC structures as repair techniques [5-8]. Impregnated silicate compound such as colloidal silicate and $\mathrm{Na}$-silicate through capillary suction reacts with the calcium hydroxide- $\mathrm{Ca}(\mathrm{OH})_{2}$ in concrete and produces additional CSH gel [9]. Through the reaction with $\mathrm{SiO}_{2}$ and $\mathrm{Ca}(\mathrm{OH})_{2}$, the pore structure in concrete is modified to be more denser and invisible micro cracks can be closed. The other is a development of repair system using silicate compound and the related equipment. The organic surface impregnant is mainly used for waterproofing and surface protection since it has several advantages like low price and easy coating process. However, most of them are basically constituted of volatile organic compound and they have the decisive shortcoming of being air-polluting during manufacturing process as well as coating works [8]. Besides the environmental problem, delamination of impregnation layer easily occurs since organic coating cannot distribute the evaporation from inner concrete to outside. In addition, the material behaviors like shrinkage and thermal expansion in organic coating are significantly different from those in concrete [2]. These disharmonious characteristics of surface layer cause cracks, delamination, and coming-off from the concrete surface $[2,8,10]$. The pores and cracks in concrete become such main routes 


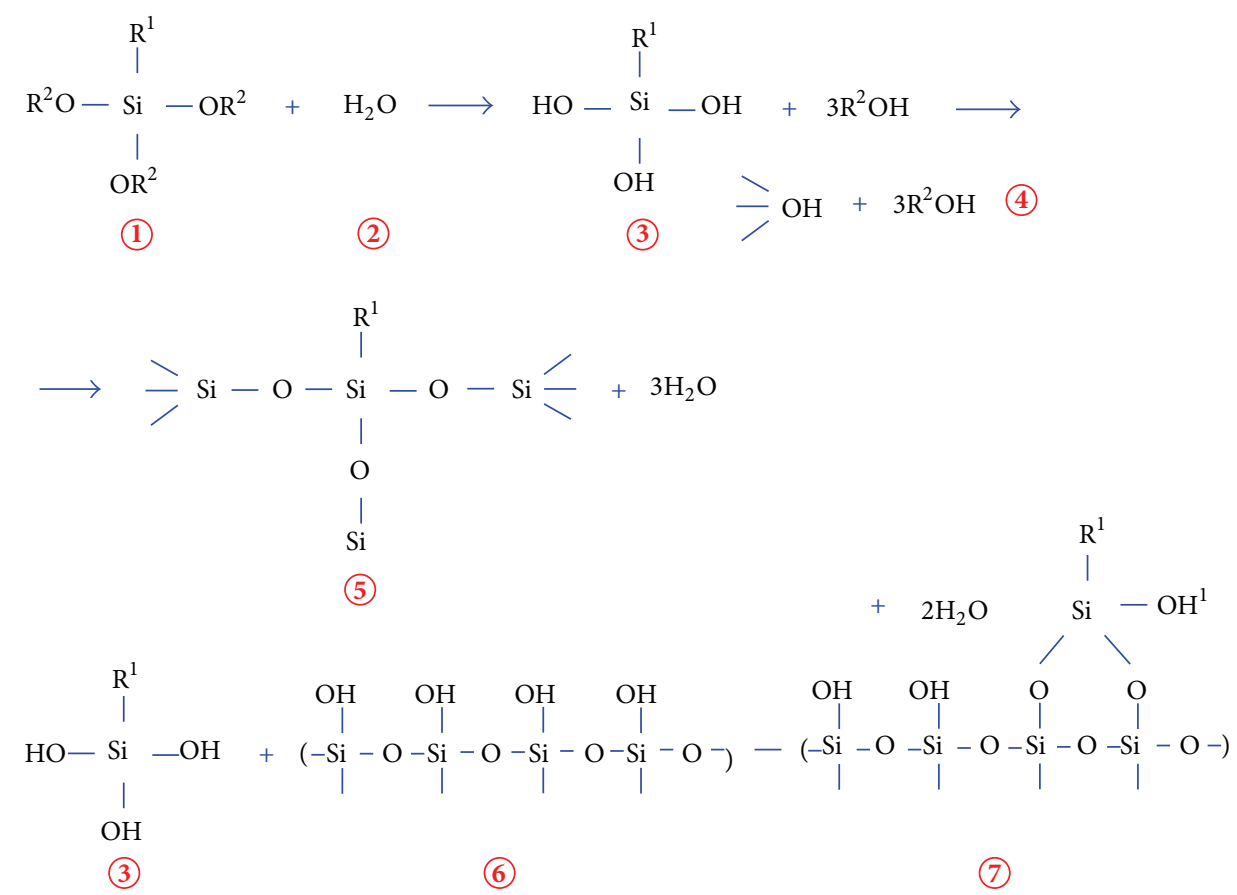

Figure 1: Chemical chain in inorganic impregnant.

for deteriorating agents that durability improvement can be obtained through reducing porosity and permeability [11-14], Long-term exposure tests for surface-impregnated concrete are limitedly performed while accelerated deterioration tests in laboratorial scale are widely carried out.

This paper presents an enhanced performance of concrete with impregnation of organic and combined type. For the purpose, two types of surface impregnants which are inorganic type and combined type are applied to two different concrete levels. Properties evaluation tests including porosity, chloride diffusion coefficient, compressive strength, permeation of water and air, and moisture absorption are performed. Through long-term exposure tests, chloride behaviors and electrical potential for steel corrosion are evaluated for the surface-impregnated concrete. Quantitative improvement of material properties and resistance to chloride attack in concrete with surface impregnation are evaluated and discussed in this paper.

\section{Mechanism of Engineering Properties Enhancement through Surface Impregnation}

2.1. Denser Pore Structure with Intrusion of Silicate Compound. Among the silicate components such as calcium silicate, potassium silicate, and colloid silica which make pore structure denser through reaction of rehydration, sodium silicate $\left(\mathrm{Na}_{2} \mathrm{O}-\mathrm{SiO}_{2}\right)$ is recently utilized for repair technique. Through capillary suction into concrete, this silicate compound reacts with calcium hydroxide and eventually forms insoluble $\mathrm{CSH}$ gel $\left(\mathrm{Ca}-\mathrm{SiO}_{2}\right)$ which makes concrete denser $[6-8,15]$. Namely, the porosity in concrete is reduced through the reaction with intruded silicate compound and residual $\mathrm{Ca}(\mathrm{OH})_{2}$, which generally occupies $25-30 \%$ of amount of $\mathrm{CSH}$ in concrete [16]. In the conventional repair system with plate-bonding technique, organic adhesive such as epoxy resin is usually used but it cannot guarantee the durability performance under severe condition because of delamination of protection layer $[2,17,18]$. The material property of reproduced $\mathrm{CSH}$ gel in impregnation layer has the same material property as concrete, which enables perfect bond without delamination of impregnation layer. The delamination and peeling-off of coating layer frequently occur in organic coating on concrete surface [8].

The reactions of inorganic and combined type of impregnation applied in this study are written in (1) and (2), respectively $[6,7]$ :

$$
\begin{aligned}
& \mathrm{Na}_{2} \mathrm{SiO}_{3}+\mathrm{yH}_{2} \mathrm{O}+\mathrm{xCa}(\mathrm{OH})_{2} \\
& \quad \longrightarrow \mathrm{xCa} \cdot \mathrm{SiO}_{2} \cdot \mathrm{yH}_{2} \mathrm{O}+2 \mathrm{NaOH} \\
& \mathrm{R}_{2} \mathrm{O} \cdot \mathrm{SiO}_{2}+\mathrm{xCaCl}+\mathrm{yH}_{2} \mathrm{O} \\
& \quad \longrightarrow \mathrm{xCaO} \cdot \mathrm{SiO}_{2} \cdot \mathrm{yH}_{2} \mathrm{O}+\mathrm{ROH}
\end{aligned}
$$

In Figure 1, chemical compound in inorganic impregnant is shown.

2.2. Reduced Chloride Penetration through Surface-Impregnation. In hardened concrete, chloride ion can be divided into free chloride ion affecting steel corrosion directly and bound chloride ion, chemically stable without exposure to severe environmental condition like carbonation $[19,20]$. Formation of bound chloride can be expressed as (3) through the reaction with soluble $\mathrm{CaCl}_{2}$ and monosulfate. Similar 


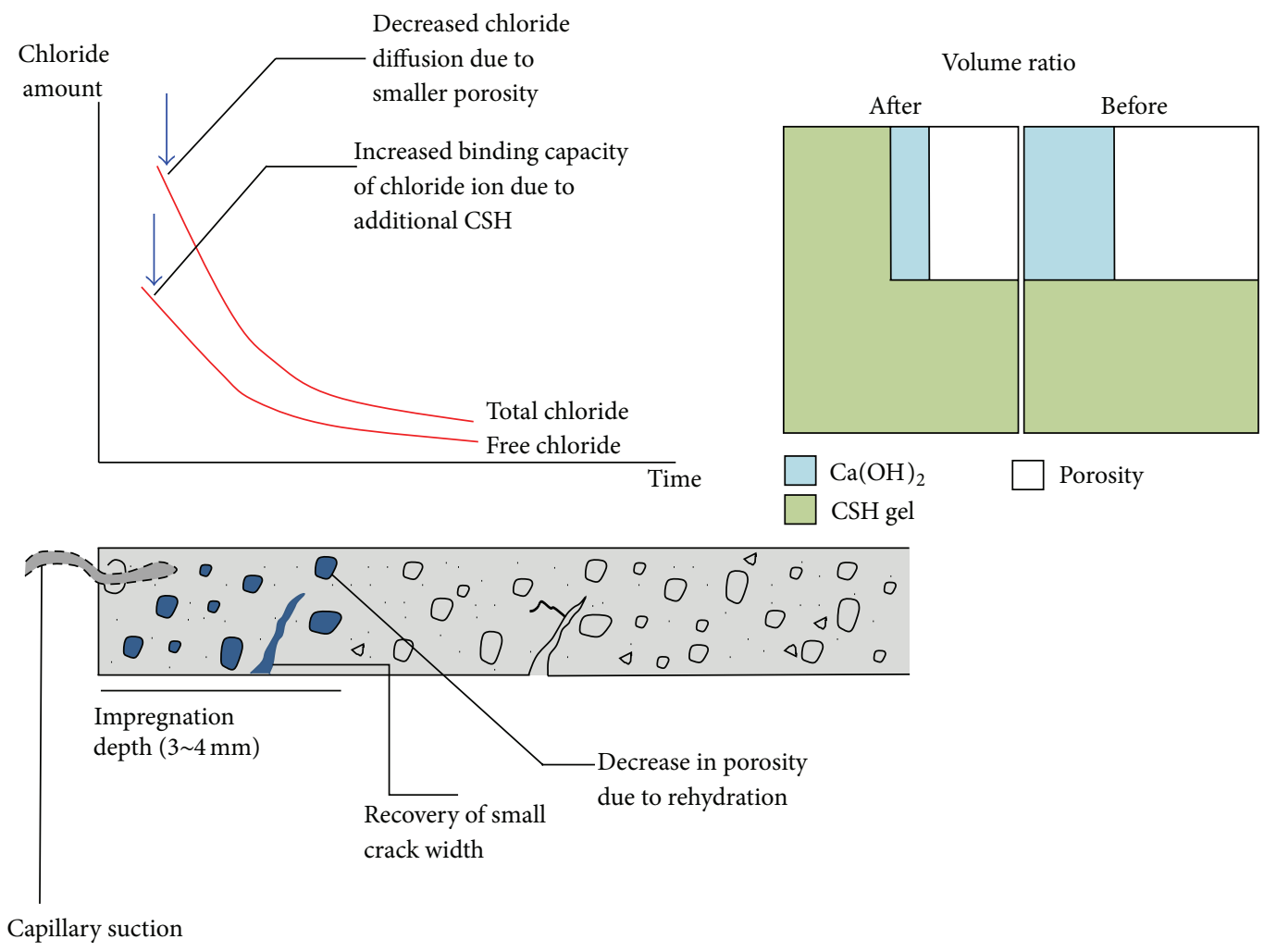

FIGURE 2: Durability improvement in surface-impregnated concrete.

TABLE 1: Characteristics of applied surface impregnants.

\begin{tabular}{|c|c|c|c|c|c|c|}
\hline \multicolumn{2}{|r|}{ Type } & Main ingredient & Color & Viscosity (cp) & Surface tension (dyne/cm) & Solvent \\
\hline $\mathrm{I}$ & Inorganic & Sodium silicate & No color & 3.72 & 26.0 & Alcohol \\
\hline $\mathrm{C}$ & Combined inorganic/organic & Sodium silicate + polymer & Sky blue & 4.13 & 38.0 & Water \\
\hline
\end{tabular}

as (3), soluble $\mathrm{CaCl}_{2}$ can be changed into insoluble silicate compound through intrusion of silicate compound as shown in (4):

$$
\begin{gathered}
3 \mathrm{CaO} \cdot \mathrm{Al}_{2} \mathrm{O}_{3} \cdot \mathrm{CaSO}_{4} \cdot 12 \mathrm{H}_{2} \mathrm{O}+\mathrm{CaCl}_{2} \\
\longrightarrow \mathrm{C}_{3} \mathrm{~A} \cdot \mathrm{CaCl}_{2} \cdot 10 \mathrm{H}_{2} \mathrm{O}+\mathrm{CaSO}_{4} \\
\mathrm{R}_{2} \mathrm{O} \cdot \mathrm{SiO}_{2}+\mathrm{xCaCl}_{2}+\mathrm{yH}_{2} \mathrm{O} \\
\longrightarrow \mathrm{xCaO} \cdot \mathrm{SiO}_{2} \cdot \mathrm{yH}_{2} \mathrm{O}+\mathrm{ROH}
\end{gathered}
$$

According to the previous researches [21], chloride ion in pore water can be changed into bound chloride ion through absorption to $\mathrm{CSH}$ gel and it is related with the amount of CSH gel. The resistance to chloride attack can be obtained through both increase in bound chloride ion due to reproduced $\mathrm{CSH}$ and decrease in diffusion of chloride ion due to reduced pore structure in surface-impregnated layer. If the property of concrete surface is improved, it can provide an effective resistant barrier to chloride attack. These durability characteristics using improved skin properties are verified by both experiments [5] and analytical solution [22]. The enhancing resistance to chloride attack by surfaceimpregnated concrete can be summarized as Figure 2 .

\section{Experimental Program}

3.1. Materials Used. In this paper, two surface impregnants are applied to concrete samples with two different mix proportions. One is the inorganic type (I) and the other is the combined inorganic and organic type (C). The properties of applied impregnants are listed in Table 1. The mix proportions of concrete and the physical properties of aggregates are listed in Tables 2 and 3, respectively.

3.2. Experiment Procedures. The experiment program in this paper has two parts; one is for evaluation of enhancing properties after impregnation and the other is for durability evaluation under chloride attack for 2 years in exposure test.

\subsubsection{Enhancing of Engineering Properties through Surface-Impregnation}

(1) Curing and Impregnation. The tests for enhancement of engineering properties include porosity measurement, chloride diffusion coefficient, compressive strength, permeability of air/water, and water absorption ratio. Concrete samples are mixed based on Table 2 and threefold samples are 
TABLE 2: Mixture proportions of concrete.

\begin{tabular}{lccccccc}
\hline $\mathrm{MPa}$ & Slump $(\mathrm{cm})$ & $\mathrm{w} / \mathrm{c}(\%)$ & $\mathrm{S} / \mathrm{a}$ & $\mathrm{W}\left(\mathrm{kg} / \mathrm{m}^{3}\right)$ & $\mathrm{C}\left(\mathrm{kg} / \mathrm{m}^{3}\right)$ & $\mathrm{S}\left(\mathrm{kg} / \mathrm{m}^{3}\right)$ & $\mathrm{G}\left(\mathrm{kg} / \mathrm{m}^{3}\right)$ \\
\hline 21 & 15 & 55.4 & 45.8 & 166 & 267 & 810 & 979 \\
34 & 15 & 48.7 & 43.0 & 185 & 380 & 731 & 994 \\
\hline
\end{tabular}

S/a: ratio of sand to total aggregate; W: water; C: cement; S: Sand; G: gravel.

TABLE 3: Physical properties of aggregates.

\begin{tabular}{lcccc}
\hline Type & $G_{\max }(\mathrm{mm})$ & Density $\left(\mathrm{g} / \mathrm{cm}^{3}\right)$ & Absorption $(\%)$ & Fineness modulus \\
\hline Fine aggregate & - & 2.60 & 0.95 & 2.64 \\
Coarse aggregate & 25 & 2.65 & 0.85 & 6.80 \\
\hline
\end{tabular}

TABLE 4: Specimens and curing procedures.

\begin{tabular}{lcc}
\hline Test & Specimens (mm) & Curing and impregnation \\
\hline Porosity & $50 \times 50 \times 50$ (cubic) & (1) Mixing based on Table 2 \\
Chloride diffusion coefficient & $100 \times 50$ (cylinder) & (2) Curing in air for 1 day \\
Compressive strength & $100 \times 200$ (cylinder) & (3) Curing in water for 4 weeks \\
Permeability of water and air & $200 \times 200 \times 100$ (rectangular) & (4) Drying in air for 2 weeks \\
Absorption & $100 \times 100 \times 100$ (cubic) & (5) Spraying impregnant \\
\hline
\end{tabular}

manufactured for each test. Each sample is demolded after 1 day and cured in submerged condition $\left(20^{\circ} \mathrm{C}\right.$ of temperature) for 4 weeks. After curing for 4 weeks, they are exposed to air for 2 weeks and then surface impregnation was performed through spraying. The test items, size of sample, and curing procedures are summarized in Table 4.

(2) Tests for Impregnated Concrete. For the control concrete (21 $\mathrm{MPa}$ and $34 \mathrm{MPa}$ ) and impregnated concrete (I and $\mathrm{C}$ type), porosity is measured through mercury intrusion porosimetry (MIP). The porosity in impregnated concrete is reduced through additionally reproduced $\mathrm{CSH}$ so that durability performance can be improved. They are measured based on the related guideline [23]. For design of durability, chloride diffusion coefficient is essential parameter. In this test, accelerated test in nonstationary condition is performed based on the previous research [24]. Chloride diffusion coefficient can be obtained as follows:

$$
\begin{aligned}
& D_{\mathrm{cpd}}=\frac{R T L}{z F U} \cdot \frac{x_{d}-\alpha \sqrt{x_{d}}}{t}, \\
& \alpha=2 \sqrt{\frac{R T L}{z F U}} \cdot \operatorname{erf}^{-1}\left[1-\frac{2 C_{d}}{C_{0}}\right],
\end{aligned}
$$

where $D_{\text {cpd }}$ is diffusion coefficient in nonsteady state condition from rapid chloride penetration test $\left(\mathrm{m}^{2} / \mathrm{sec}\right), R$ is universal gas constant $(8.314 \mathrm{~J} / \mathrm{mol} \cdot \mathrm{K}), T$ is absolute temperature $(\mathrm{K}), L$ is thickness of specimen $(\mathrm{m}), z$ is ionic valence $(=1.0), F$ is Faraday constant $(=96,500 \mathrm{~J} / \mathrm{V} \mathrm{mol}), U$ is applied potential (V), $x_{d}$ is the penetration depth of chloride ion $(\mathrm{m}), t$ is test duration time $(\mathrm{sec}), C_{0}$ is chloride concentration in the upstream solution $(\mathrm{mol} / \mathrm{L}), C_{d}$ is chloride concentration at the chloride penetration front $(\mathrm{mol} / \mathrm{L})$, and $\operatorname{erf}^{-1}$ is the inverse of the error function.

Compressive strength is considered as basic parameter for property evaluation so that compressive strength test is also performed referring KS F 2405 [25]. Permeabilities of water and air have important roles of durability performance since they are directly related to moisture transport. Because concrete in partially saturated condition always has moisture gradient, evaporation occurs on the surface. When the inorganic material without moisture evaporation to outer surface is coated, it causes delamination and peeling-off of coating material [8]. The permeability of water and air can be calculated through (6) and (7), respectively $[6,7]$ :

$$
\begin{gathered}
C_{C P}=\frac{q}{P / L} \\
K=4\left[\frac{V_{c}\left(d P_{I} / d t\right)^{2}}{A\left(P_{a}^{2}-P_{I}^{2}\right)}\right] \frac{\mu P_{a}}{\varepsilon} \int_{t_{0}}^{t}\left[1-\left(\frac{P_{I}}{P_{a}}\right)^{2}\right] d t,
\end{gathered}
$$

where $C_{C P}$ is permeability of water $\left(\mathrm{m}^{2} / \mathrm{sec}\right), q$ is velocity ( $\mathrm{m} / \mathrm{sec}), P$ is pressure (BAR), $L$ is depth of gasket $(15 \mathrm{~mm})$, $K$ is permeability of air $\left(\mathrm{m}^{2}\right), \varepsilon$ is porosity in concrete $\left(1 / \mathrm{m}^{3}\right)$, $A$ is area of chamber, $\mu$ is dynamic viscosity of air $\left(\mathrm{Ns} / \mathrm{m}^{2}\right), P_{I}$ and $P_{a}$ are pressure in chamber and air, respectively $\left(\mathrm{N} / \mathrm{m}^{2}\right)$, and $V_{c}$ is volume of chamber $\left(\mathrm{m}^{3}\right)$.

In order to obtain absorption ratios for the different concrete samples, the impregnated specimens kept in submerged condition for 72 hours after curing shown in Table 4 based on KS F 2459 [26]. The absorption ratio can be obtained through

$$
A=\frac{W_{2}-W_{1}}{W_{1}} \times 100
$$

where $A$ is absorption ratio (\%) and $W_{1}(\mathrm{~g})$ and $W_{2}(\mathrm{~g})$ are weight of specimens before and after the submerged condition, respectively.

\subsubsection{Enhancing Durability through Surface-Impregnation}

(1) Compressive Strength. Test method and mix design for concrete are same as those for compressive strength test 


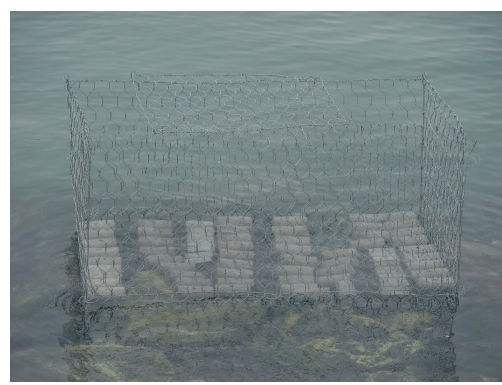

(a) Exposure to tidal condition

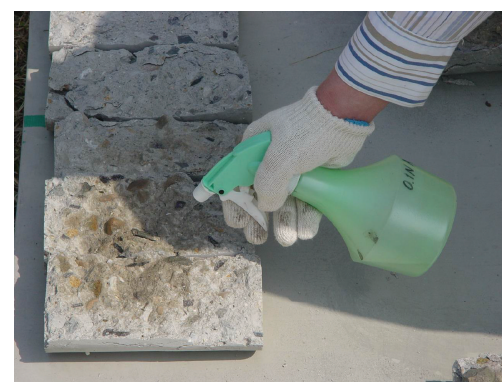

(b) Spraying $0.1 \mathrm{~N} \mathrm{AgNO}_{3}$

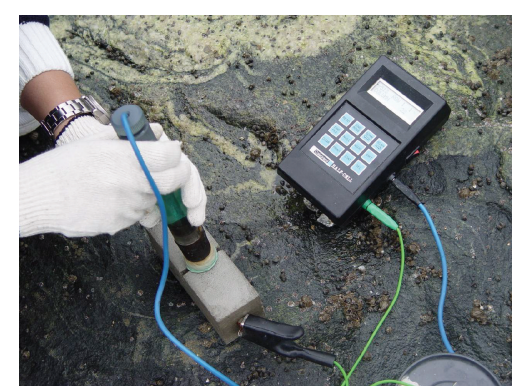

(c) Test for HCP

FIgURe 3: Photos for long-term chloride exposure test.

described in Section 3.2.1. The concrete specimens are cured for 2 weeks in submerged condition and impregnation is performed after 2 weeks of exposure to air. After impregnation, they are exposed to tidal zone of sea water. The compressive strength is evaluated at the age of 28 days, 90 days, 360 days, and 720 days. Three concrete samples are prepared for average value in the each measuring time.

(2) Chloride Penetration Depth. The cylindrical samples $(100 \mathrm{~mm} \times 200 \mathrm{~mm})$ with same curing and impregnation procedures are prepared and exposed to chloride conditions. The samples with $21 \mathrm{MPa}$ are exposed to atmospheric (saltsprayed), tidal, and sea water submerged conditions. Those with $34 \mathrm{MPa}$ are exposed to only tidal condition. For the measurement of chloride penetration depth, splitting test is performed and $\mathrm{AgNO}_{3}$ solution (0.1N) as an indicator is sprayed on the split section based on the previous research [27]. For measurement of chloride penetration depth, the colored depths are measured 10 times with $10 \mathrm{~mm}$ interval and the averages are used. It is reported that color in split layer changes when free chloride concentration reaches $0.15 \%$ (cement weight) through $0.1 \mathrm{~N} \mathrm{AgNO}_{3}$ indicator. For the sake of convenience, colorimetric method of $0.1 \mathrm{~N} \mathrm{AgNO}_{2}$ is adopted in this paper. The optimum indicator and procedures vary with test methods and chloride concentration. The reactive indicators with various colorimetric methods are well summarized in the reference [28].

(3) Electrical Potential for Steel Corrosion. For evaluation of steel corrosion, electrical potentials (Half Cell Potential) are measured for RC samples $(50 \times 50 \times 400 \mathrm{~mm})$ based on ASTM C 876-80 [29]. The conditions of curing and exposure for this test are same as those for chloride penetration depth. Steel reinforcement of $10 \mathrm{~mm}$ diameter is embedded in RC specimen which has $20 \mathrm{~mm}$ cover depth. The exposed rebar from concrete surface is coated with epoxy for preventing corrosion. In Figure 3, photos for long-term chloride exposure tests are shown.

(4) Chloride Content Evaluation (Acid-Soluble). In order to evaluate the chloride content exposed to chloride attack, cylindrical samples $(100 \times 200 \mathrm{~mm})$ are exposed to tidal and submerged conditions. For 1-dimensional intrusion, side and bottom are coated with epoxy and only top surface is directly exposed to sea water. Based on AASHTO T 260, standard solution of $\mathrm{AgNO}_{3}$ is used for determining the chloride content. After grinding concrete cover with $10 \mathrm{~mm}$ depth, the particles are tested with adding $\mathrm{HNO}_{3}$.

\section{Results and Discussion}

4.1. Improved Properties of Surface-Impregnated Concrete. Porosity in the case of $21 \mathrm{MPa}$ decreases to $62.8 \sim 74.4 \% \mathrm{com}$ pared with control results. Results in the case of $34 \mathrm{Mpa}$ show reduction to $45.4 \sim 91.7 \%$ and they are reduced significantly since they have more $\mathrm{Ca}(\mathrm{OH})_{2}$ which can react with silicate compound. Pores in concrete are much related with diffusion mechanism so that reduced chloride diffusion coefficient can be obtained through impregnation. Chloride diffusion coefficient decreases to $85 \%(21 \mathrm{MPa})$ and $71.6 \sim 74.8 \%(34 \mathrm{MPa})$. When we assume $100 \mathrm{~mm}$ of cover depth and critical chloride content of $1.2 \mathrm{~kg} / \mathrm{m}^{3}$, service life is evaluated to increase from 37.8 years to 50.5 year through simply spraying I type impregnant to $34 \mathrm{MPa}$ concrete based on Fick's 2nd Law [30]. For compressive strength, it is measured that results in both impregnated concrete samples slightly increase because material properties are improved only within the impregnated depth (below $10 \mathrm{~mm}$ ). No significant development in strength is measured in the test. The strength gaining ratios are evaluated to be $112.4-121.2 \%$ (for $21 \mathrm{MPa}$ concrete) and $114.1-116.1 \%$ (for $34 \mathrm{MPa}$ concrete). Permeability of water/air is the unique characteristics of porous media like concrete. It is strongly related with transport of external agents so that it can be used as durability index [31]. In water permeability test, reduction ratios to control samples are measured to be $45.4-50.0 \%$ in surface-impregnated concrete with $21 \mathrm{MPa}$ and $25.6-27.3 \%$ in that with $34 \mathrm{MPa}$. In air permeability test, reduction ratios are also measured to be $86.7 \%$ in surfaceimpregnated concrete with $21 \mathrm{MPa}$ and $85.0-90.0 \%$ in that with $34 \mathrm{MPa}$, respectively. Similarly as the results of compressive strength, there is no significant difference from the impregnant types. While the surface-impregnated concrete shows significantly reduced water permeability, the effect of impregnation on air permeability seems to be marginal. As previously explained, delamination between concrete and surface coating easily occur in organic impregnated concrete since coating on surface cannot permit evaporation to outer surface $[2,6-8,10]$. The improved property with lowering water permeability but maintaining air permeability is 
TABLE 5: Summary of modified properties tests.

\begin{tabular}{|c|c|c|c|c|c|c|}
\hline \multirow{2}{*}{ Test items } & \multicolumn{3}{|c|}{ Concrete- $21 \mathrm{MPa}(\%$ to control of $21 \mathrm{MPa})$} & \multicolumn{3}{|c|}{ Concrete-34 Mpa (\% to control of $34 \mathrm{MPa}$ ) } \\
\hline & Control & C type & I type & Control & C type & I type \\
\hline Porosity (\%) & $25.8(100.0)$ & $19.2(74.4)$ & $16.2(62.8)$ & $20.2(100.0)$ & $18.5(91.7)$ & $9.2(45.4)$ \\
\hline Chloride diffusion coefficient $\left(\mathrm{m}^{2} / \mathrm{sec}\right)$ & $2.61(100.0)$ & $2.23(85.4)$ & $2.23(85.4)$ & $1.55(100.0)$ & $1.11(71.6)$ & $1.16(74.8)$ \\
\hline Compressive strength (MPa) & $25.0(100.0)$ & $28.1(112.4)$ & $30.3(121.2)$ & $29.8(100.0)$ & $34.0(114.1)$ & $34.6(116.1)$ \\
\hline Water permeability $\left(10^{-14} \mathrm{~m} / \mathrm{sec}\right)$ & $170.7(100.0)$ & $85.4(50.0)$ & $77.6(45.4)$ & $153.8(100.0)$ & $42.0(27.3)$ & $39.4(25.6)$ \\
\hline Air permeability $\left(10^{-16} \mathrm{~m}^{2}\right)$ & $2.3(100.0)$ & $2.0(86.9)$ & $2.0(86.9)$ & $2.0(100.0)$ & $1.8(90.0)$ & $1.7(85.0)$ \\
\hline Absorption (\%) & $2.7(100.0)$ & $0.7(25.7)$ & $0.5(16.9)$ & $2.1(100.0)$ & $0.5(25.9)$ & $0.4(18.5)$ \\
\hline
\end{tabular}

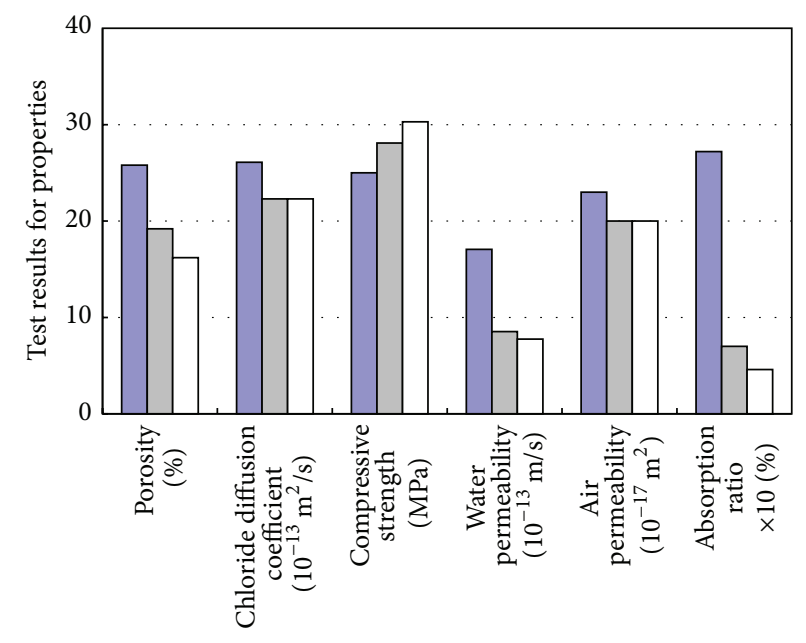

- Control

a C type

- I type

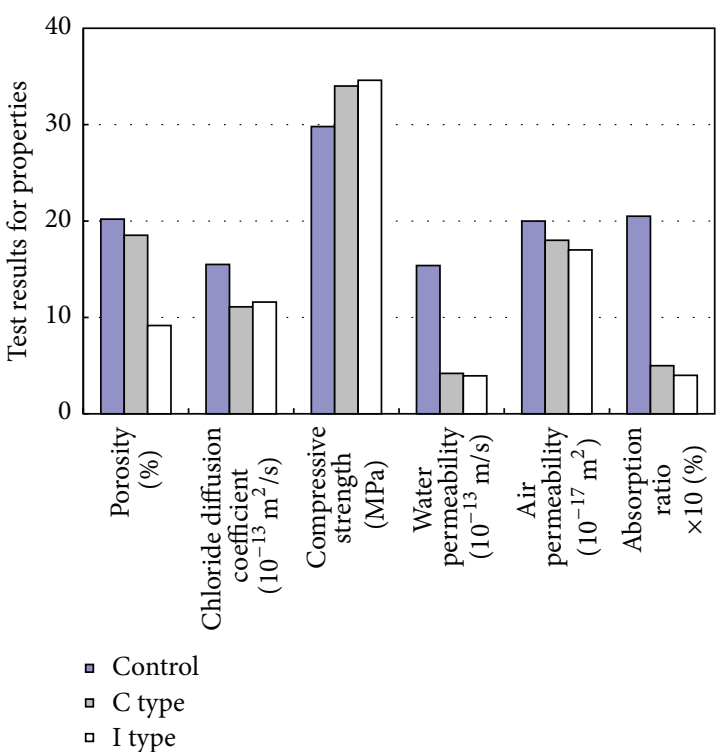

(b) Results for concrete of $34 \mathrm{MPa}$

(a) Results for concrete of $21 \mathrm{MPa}$

FIGURE 4: Results for modified properties test.

a notable engineering advantage and this can prevent the delamination of impregnated layer. The surface-impregnated concrete has hydrophobic characteristics so that it can reduce the intrusion of water. Reduction ratios in absorption test are measured to be $16.9-25.7 \%$ in surface-impregnated concrete with $21 \mathrm{MPa}$ and $18.5-25.9 \%$ in that with $34 \mathrm{MPa}$. For overall test results, the concrete with inorganic coating (I type) shows slightly better enhanced performances both in concrete of $21 \mathrm{MPa}$ and $34 \mathrm{MPa}$. The results for improved properties are summarized in Table 5 and Figure 4. Figures 4(a) and 4(b) show the results of impregnated concrete of $21 \mathrm{MPa}$ and $34 \mathrm{MPa}$, respectively.

The effect of surface impregnation on engineering properties is evaluated to be remarkable in reducing porosity, water permeability, and absorption ratio among the others.

\subsection{Durability Evaluation for Surface-Impregnated Concrete}

4.2.1. Compressive Strength in Long-Term Exposure to Chloride Attack. As shown in Figure 5, compressive strength in impregnated concrete shows increase with exposure period but no clear strength gaining. The impregnated depth is usually 5-6 mm when it is sprayed. In the results in Table 5, strength increasing ratios are 112.4-121.2\%, however the results in this section are different from those in Table 5 because of their different curing conditions and period. It is recommended to take a conservative repair strategy through disregarding an increase in strength. Slight increase in compressive strength is measured in surface-impregnated concrete with $21 \mathrm{MPa}$, while it is goes down to $92.6-94.5 \%$ in $34 \mathrm{MPa}$ concrete. Considering the harsh environmental condition like tidal zone where physical and chemical attacks act simultaneously, the difference of measured strength seems to be small.

4.2.2. Chloride Penetration Depth in Long-Term Exposure to Chloride Attack. The measurements of the chloride penetration depth with different exposure conditions are shown in Figure 6. As described in Section 3.2.2, samples with $21 \mathrm{MPa}$ are located in 3 different conditions like atmospheric, tidal, and submerged condition. Those with $34 \mathrm{MPa}$ are located only in tidal condition.

In durability design, the chloride penetration depth with critical chloride amount (i.e., $1.2 \mathrm{~kg} / \mathrm{m}^{3}$ ) should be smaller than the cover depth within the intended service period since 


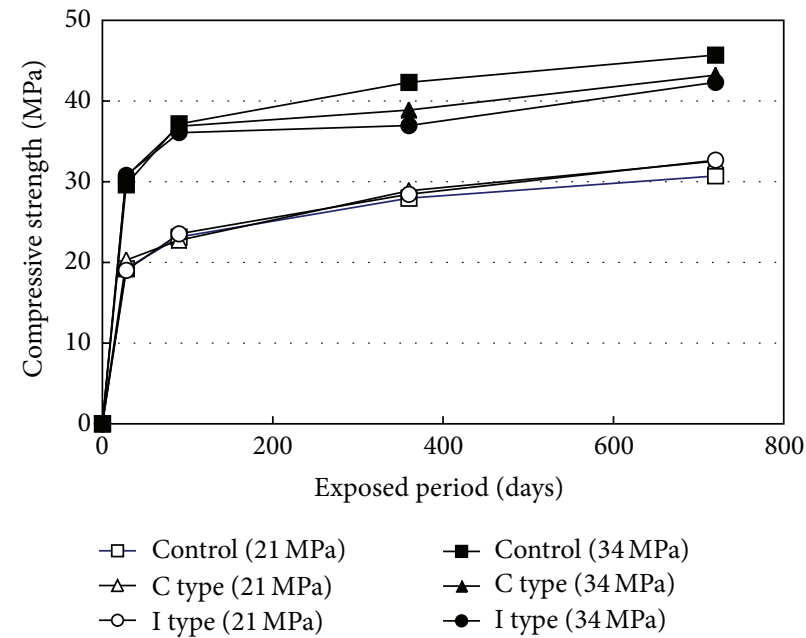

FIGURE 5: Change in compressive strength in surface-impregnated concrete under long-term exposure condition.

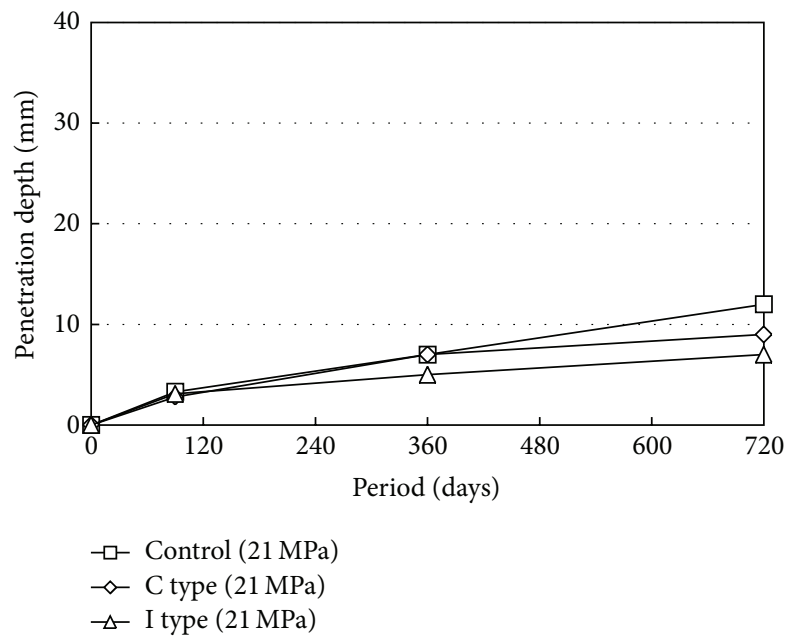

(a) $21 \mathrm{MPa}$ atmospheric condition

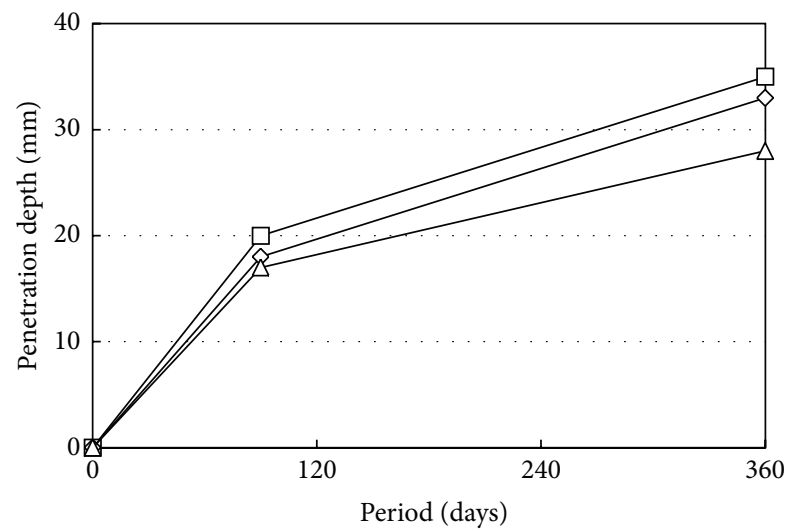

$\neg-$ Control (21 MPa)

$\diamond$ C type $(21 \mathrm{MPa})$

$\triangle-$ I type (21 MPa)

(c) $21 \mathrm{MPa}$ : submerged condition

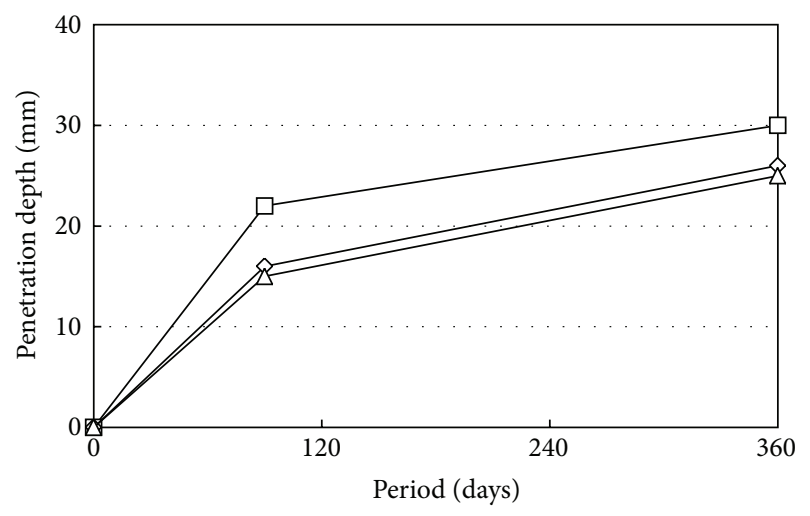

$\square-$ Control (21 MPa)

$\neg$ C type $(21 \mathrm{MPa})$

$\neg-$ I type (21 MPa)

(b) $21 \mathrm{MPa}$ : tidal condition

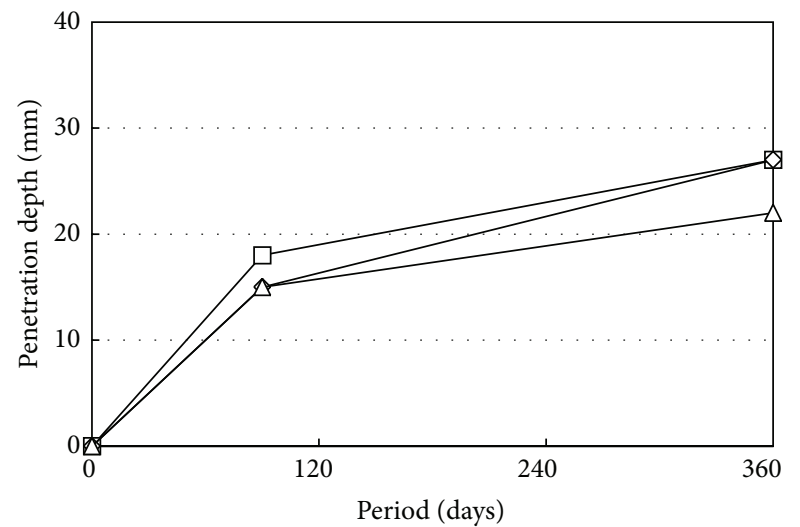

$\neg-$ Control (34 MPa)

$\neg$ C type $(34 \mathrm{MPa})$

$\triangle-$ I type (34 MPa)

(d) $34 \mathrm{MPa}$ : tidal condition

FIGURE 6: Chloride penetration depth in surface-impregnated concrete. 
TABLE 6: Decrease ratio of chloride penetration depth.

\begin{tabular}{lcccc}
\hline Period (days) & Condition & Control & C type & I type \\
\hline & & & Ratio of chloride penetration depth (21 MPa: \%) \\
360 & Tidal & 100.0 & 94.3 & 80.0 \\
360 & Submerged & 100.0 & 86.7 & 83.3 \\
720 & Salt-sprayed & 100.0 & 75.0 & 58.3 \\
\hline & & & Ratio of chloride penetration depth (34 MPa: \%) & \\
360 & Tidal & 100.0 & 100.0 & 81 \\
\hline
\end{tabular}

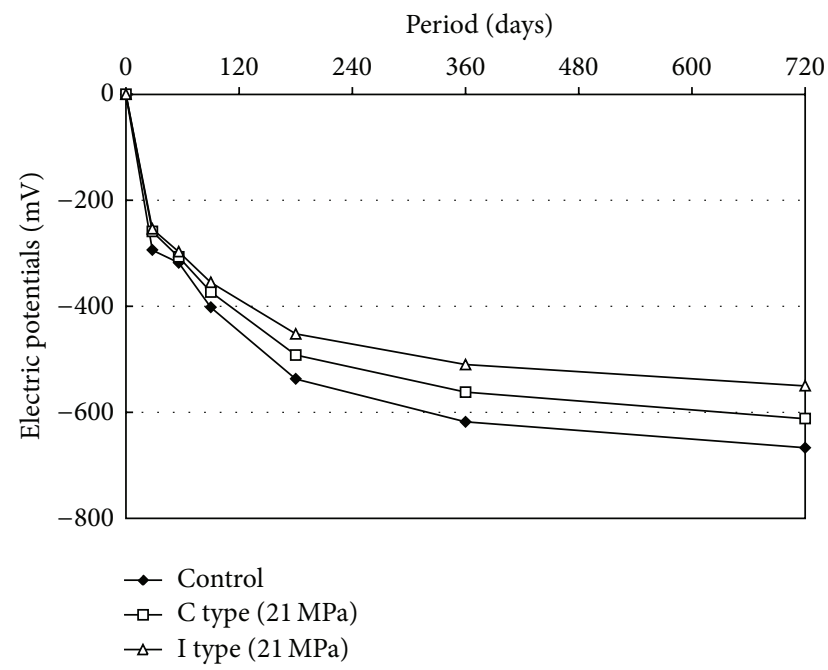

(a) Potential (21 MPa, submerged condition)

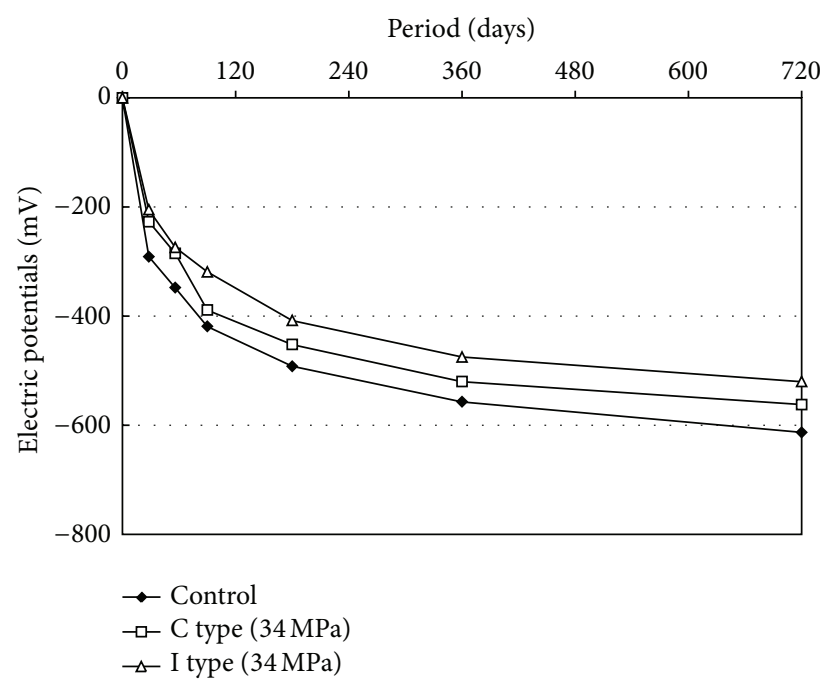

(c) Potential (34 MPa, tidal condition)

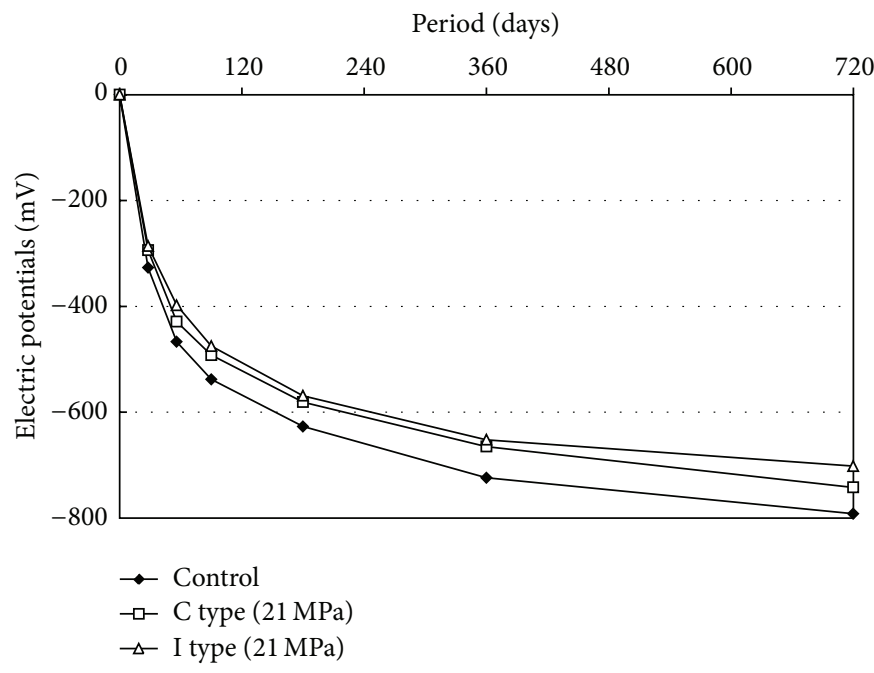

(b) Potential (21 MPa, tidal condition)

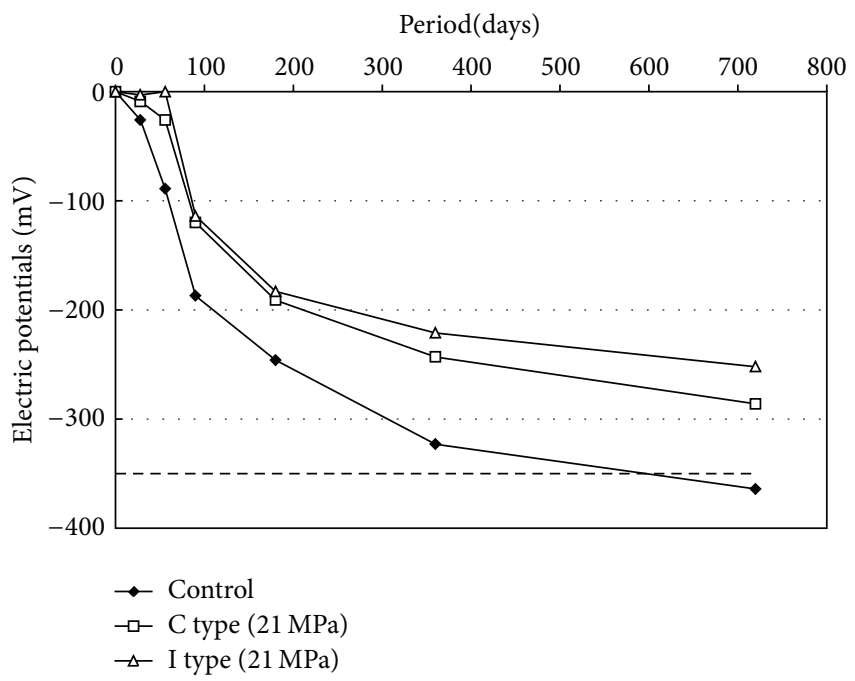

(d) Potential (21 MPa, atmospheric condition)

FIgURE 7: Result of measured potential in surface-impregnated concrete.

chloride ion is one of the most critical deteriorating agent for its rapid propagation and its direct effect on steel corrosion $[1,12,27,29]$. As shown in Figure 6, chloride penetration depth is reduced in both I and C type impregnated concrete through enhancement of surface impregnation. The concrete samples with inorganic impregnation show better resistance to chloride penetration and this trend is clear with the longer exposure period. The resistance to chloride attack is closely related to impregnation depth of silicate. The impregnation depth increases with activated capillary suction, which is caused by lower viscosity and surface tension of impregnant type [5-7]. The ratio of chloride penetration depth is listed in Table 6. Unlike strength evaluation, it shows reasonable resistance to chloride penetration. 


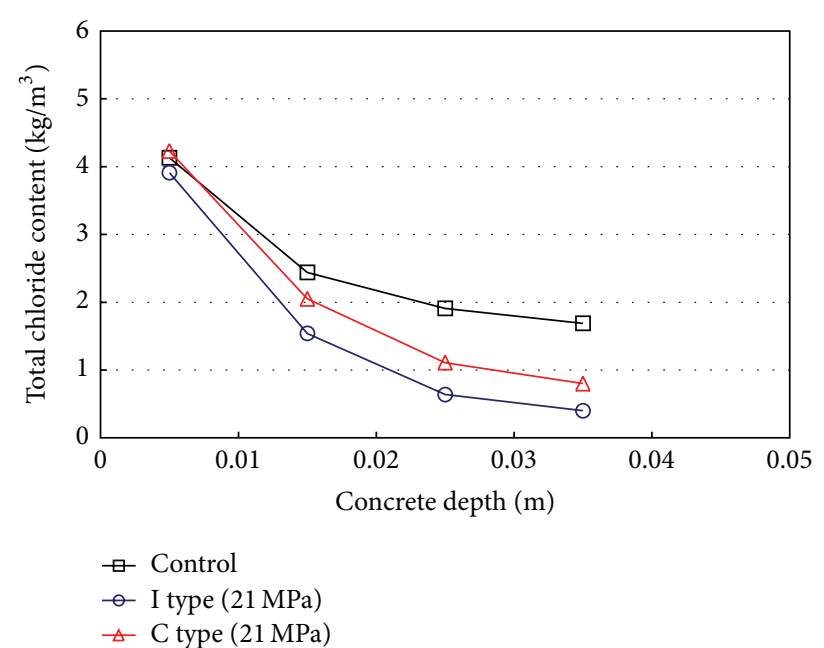

(a) Chloride profile (21 MPa, submerged condition)

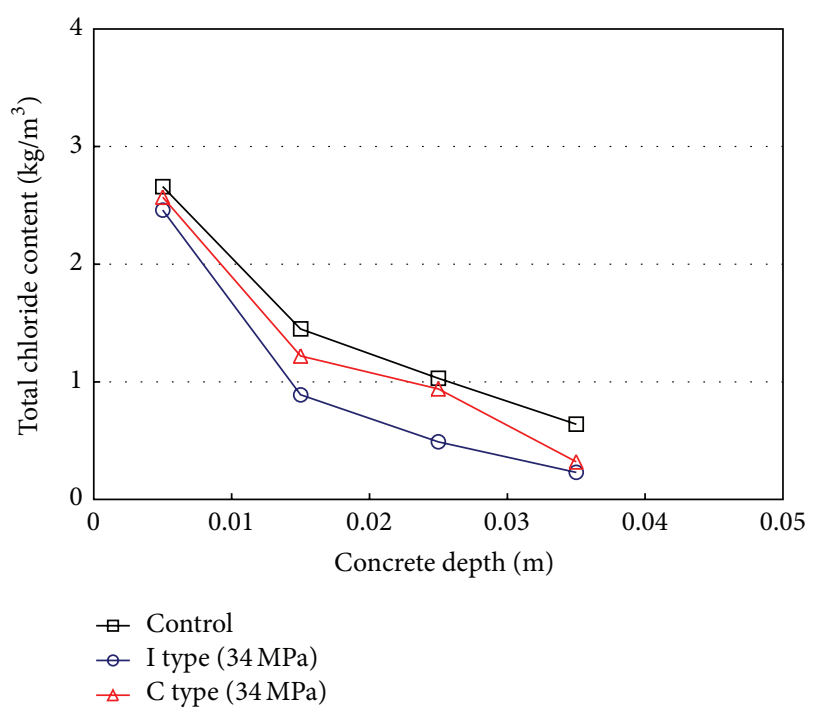

(c) Chloride profile (34 MPa, tidal condition)

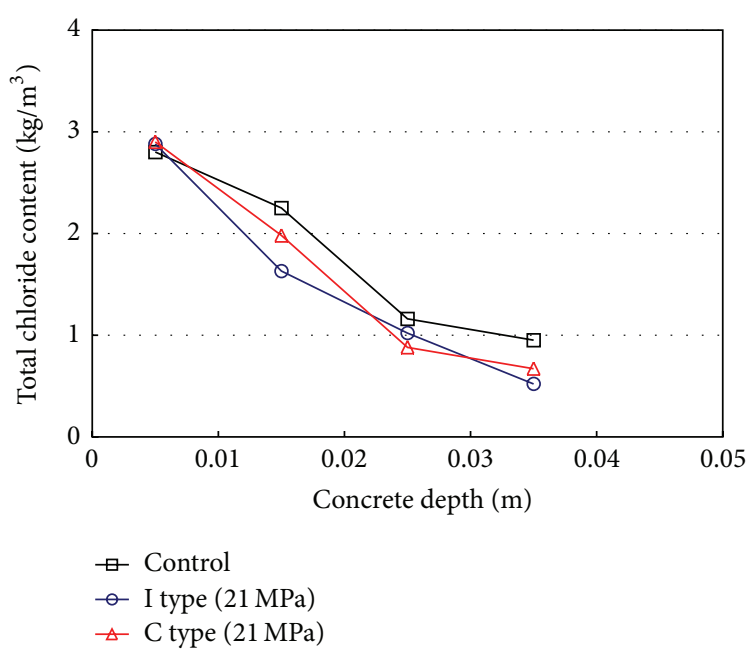

(b) Chloride profile (21 MPa, tidal condition)

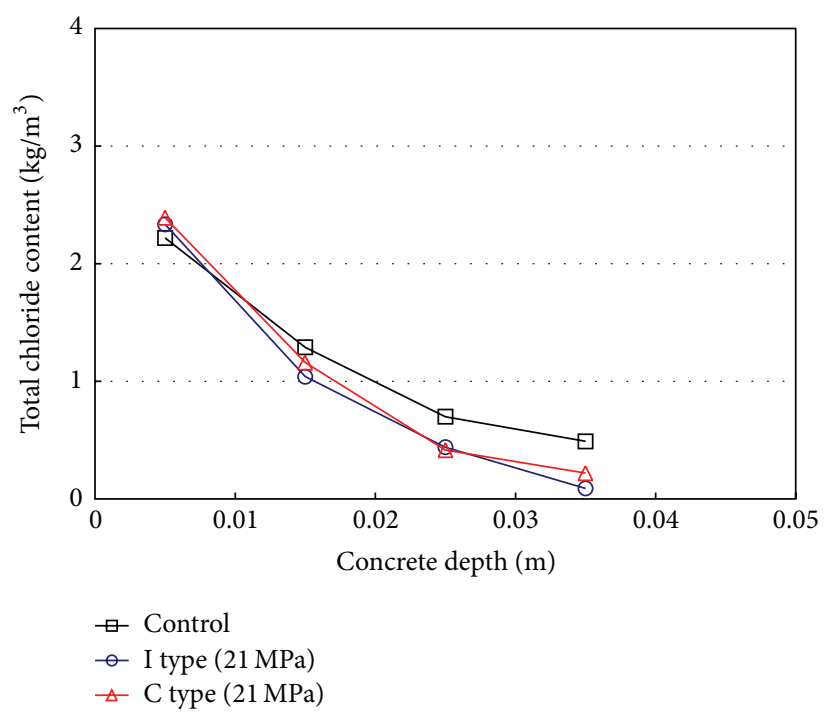

(d) Chloride profile (21 MPa, atmospheric condition)

FIGURE 8: Total chloride profile in concrete with/without impregnation after 2 years.

4.2.3. Electric Potential for Steel Corrosion (Copper-Copper Sulfate Half Cell: CSE). It is reported that steel corrosion easily occurs at the location where lower electrical potential is measured since possibility of corrosion is governed by electrical potential and resistivity around steel location [29, 32]. The results of electronic potential indicate an improved resistance to steel corrosion as shown in Figure 7.

Potential in surface-impregnated concrete with $21 \mathrm{MPa}$ in Figure (b) is evaluated to be similar as that in nonsurfaceimpregnated concrete with $34 \mathrm{MPa}$ in Figure (c). It shows that concrete with low strength can obtain reasonable resistance to chloride attack like concrete with high strength by simple spraying of surface impregnation. In every condition, concrete with I type impregnation has better resistance to steel corrosion than that with $\mathrm{C}$ type impregnation. Previously described, lower viscosity and surface tension of I type are more effective to impregnation. According to the pervious researches [31,32], probability of steel corrosion is higher than $90 \%$ in the concrete area under $-350 \mathrm{mV}$ of HCP. While the electric potential in control decreases to the level of critical value $(-350 \mathrm{mV})$ after 1.8 years, the others with impregnation show higher potential than $-350 \mathrm{mV}$ after 2 years as shown in Figure 7(d). The decrease ratios of measured electrical potential after 2 years are listed in Table 7 . The effect of impregnation is shown to be most effective in atmospheric condition since the intruded silicate compound is not distilled and impeded by water intrusion and leaching out.

4.2.4. Profiles of Total Chloride Contents. In Figure 8 chloride profiles are shown for concrete in tidal and salt-sprayed conditions. Chloride profiles in the results show impregnated concrete have improved resistance to chloride penetration. Similarly as durability test results, I type impregnation with lower viscosity and surface tension shows better resistance than C type impregnation. With simplified regression 


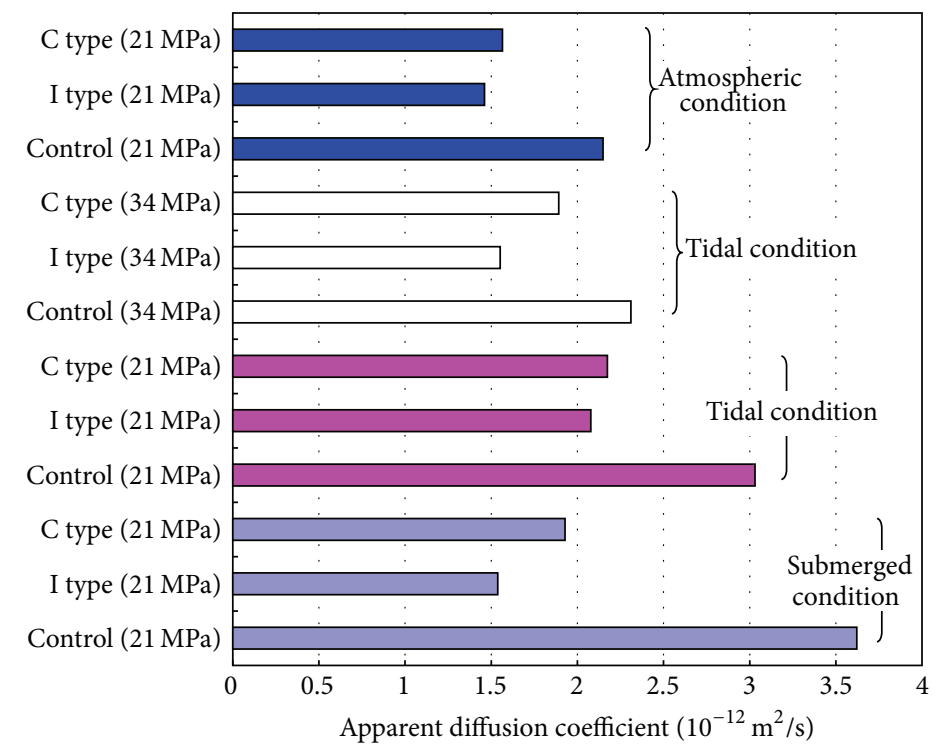

FIGURE 9: Derived apparent diffusion coefficient and surface chloride contents.

TABLE 7: Decrease ratio of electrical potential after 2 years.

\begin{tabular}{|c|c|c|c|c|}
\hline Period (days) & Condition & Control & C type & I type \\
\hline \multicolumn{5}{|c|}{ Decrease ratio of potential (21 MPa: \%) } \\
\hline \multirow{4}{*}{720} & Tidal & 100.0 & 93.6 & 88.6 \\
\hline & Submerged & 100.0 & 91.8 & 82.4 \\
\hline & Salt-sprayed & 100.0 & 78.5 & 69.2 \\
\hline & & \multicolumn{3}{|c|}{ Decrease ratio of potential (34 MPa: \%) } \\
\hline 720 & Tidal & 100.0 & 91.6 & 84.8 \\
\hline
\end{tabular}

analysis, apparent diffusion coefficients are obtained and plotted in Figure 9. The effects of reduction ratio regarding apparent diffusion coefficient are $42.5-68.6 \%$ for I type impregnation and 53.2-72.9 for $\mathrm{C}$ type impregnation.

\section{Concluding Remarks}

The conclusions on evaluation of concrete durability performance with sodium silicate impregnants are as follows.

(1) The surface-impregnated concrete shows marginal increase in compressive strength. For conservative repair design, it is reasonable not to consider the strength gaining in surface-impregnated concrete. The enhancement effects of surface impregnation are remarkably observed in reducing water permeability, absorption, and porosity.

(2) I type (inorganic) impregnated concrete has slightly better resistance to chloride penetration than the $\mathrm{C}$ type (combined inorganic/organic) impregnated concrete due to lower viscosity and surface tension, which cause deeper impregnation depth. After 360 days, it is measured that the chloride penetration depths in impregnated concrete of $21 \mathrm{MPa}$ decrease to $80.0 \sim 94.3 \%$ of those in control concrete under tidal condition, 83.3 86.7\% under submerged condition, and 58.3 75.0\% under salt-sprayed condition, respectively.

(3) After impregnation, the results of the electrical potential in concrete with $21 \mathrm{MPa}$ and $34 \mathrm{MPa}$ decrease to $69.2 \sim 91.8 \%$ and $84.8 \sim 91.6 \%$ of those in control concrete, respectively. The surface-impregnated concrete with $21 \mathrm{MPa}$ shows similar durability performance as nonsurface-impregnated concrete with $34 \mathrm{MPa}$ in electrical potentials for corrosion.

(4) Through analysis on chloride profiles, apparent diffusion coefficients are reduced to $42.5-68.6 \%$ for I type impregnation and $53.2-72.9 \%$ for $C$ type impregnation. The effect is smaller than reduction of permeability and porosity; however reasonable resistance to chloride attack can be obtained by simply spraying sodium silicate compound.

\section{Conflict of Interests}

The authors declare that there is no conflict of interests regarding the publication of this paper. 


\section{Acknowledgment}

This work was supported by the National Research Foundation of Korea (NRF) funded by the Ministry of Education (NRF-2011-0025378).

\section{References}

[1] CEB, Durable Concrete Structures-CEB Design Guide, Thomas Telford, 1992.

[2] P. H. Emmons, Concrete Repair and Maintenance Illustrated, R.S. Means Company, 1994.

[3] L. C. Bank, Composites for Construction: Structural Design with FRP Material, John Wiley \& Sons, 2006.

[4] Y. Ohama, "Recent progress in concrete-polymer composites," Advanced Cement Based Materials, vol. 5, no. 2, pp. 31-40, 1997.

[5] E. I. Yang, M. Y. Kim, B. C. Lho, and J. H. Kim, "Evaluation on resistance of chloride attack and freezing and thawing of concrete with surface penetration sealer," Journal of the Korea Concrete Institute, vol. 18, no. 1, pp. 65-72, 2006.

[6] S. J. Kwon, S. S. Park, S. M. Lee, and J. H. Kim, "A study on durability improvement for concrete structures using surface impregnant," Journal of Korea Structure Maintenance Institute, vol. 11, no. 4, pp. 79-88, 2007.

[7] S. J. Kwon, S. S. Park, S. M. Lee, and J. W. Kim, "Selection of concrete surface impregnant through durability tests," Journal of Korea Structure Maintenance Institute, vol. 11, no. 6, pp. 7786, 2007.

[8] H. Y. Moon, D. G. Shin, and D. S. Choi, "Evaluation of the durability of mortar and concrete applied with inorganic coating material and surface treatment system," Construction and Building Materials, vol. 21, no. 2, pp. 362-369, 2007.

[9] I. Narai-Sabo, Inorganic Crystallochemistry, ACSC Publications, Budapest, Hungary, 1969.

[10] KICTTEP, “Technique for water-tightness improvement of concrete surface using water tightness agent and air pressure equipment," Report for New Technology 334, 2002.

[11] S. J. Kwon, Durability analysis in cracked concrete exposed coupled chloride attack and carbonation [Ph.D. thesis], Department of Civil Engineering, Yonsei University, Seoul, Republic of Korea, 2006.

[12] H. W. Song, S. W. Pack, C. H. Lee, and S. J. Kwon, "Service life prediction of concrete structures under marine environment considering coupled deterioration," Restoration of Buildings and Monuments, vol. 12, no. 4, pp. 265-284, 2006.

[13] H. Song and S. Kwon, "Permeability characteristics of carbonated concrete considering capillary pore structure," Cement and Concrete Research, vol. 37, no. 6, pp. 909-915, 2007.

[14] H. W. Song, S. J. Kwon, K. J. Byun, and C. K. Park, "Predicting carbonation in early-aged cracked concrete," Cement and Concrete Research, vol. 36, no. 5, pp. 979-989, 2006.

[15] V. Kasselouri, N. Kouloumbi, and T. Thomopoulos, "Performance of silica fume-calcium hydroxide mixture as a repair material," Cement and Concrete Composites, vol. 23, no. 1, pp. 103-110, 2001.

[16] T. Ishida and K. Maekawa, "Modeling of PH profile in pore water based on mass transport and chemical equilibrium theory," Concrete Library International JSCE, vol. 37, no. 3, pp. 131-146, 2003.
[17] F. Tomosawa and T. Nakatsuji, "Evaluation of ACM reinforcement durability by exposure test," in Proceedings of the International 3rd Symposium on Non-Metallic (FRP) Reinforcement for Concrete Structures, vol. 2, pp. 139-146, 1997.

[18] A. Nanni, T. Boothby, K. M. Cetim, B. A. Shaw, and C. Bakis, "Environmental degradation of repaired concrete structure," in Proceedings of the 3rd International Symposium on Non-Metallic (FRP) Reinforcement for Concrete Structures, vol. 2, pp. 155-162, 1997.

[19] A. Neville, "Chloride attack of reinforced concrete: an overview," Materials and Structures, vol. 28, no. 2, pp. 63-70, 1995.

[20] K. Tuutti, "Corrosion of steel in concrete," CBI Report 482, Swedish Cement and Concrete Research Institute(CBI), Stockholm, Sweden, 1982.

[21] T. Luping and L. Nilsson, "Chloride binding capacity and binding isotherms of OPC pastes and mortars," Cement and Concrete Research, vol. 23, no. 2, pp. 247-253, 1993.

[22] C. Andrade, J. M. Díez, and C. Alonso, "Mathematical modeling of a concrete surface "skin effect" on diffusion in chloride contaminated media," Advanced Cement Based Materials, vol. 6, no. 2, pp. 39-44, 1997.

[23] Micromeritics, “AutoPore IV 9505 Operator's Manual," 2005.

[24] T. Luping and L. Nilsson, "Rapid determination of the chloride diffusivity in concrete by applying an electrical field," $A C I$ Materials Journal, vol. 89, no. 1, pp. 40-53, 1992.

[25] Korea Standard, "Method of test for compressive strength of concrete," KS F 2405, 2005.

[26] Korea Standard, "Testing method for density, water content, absorption and compressive strength of cellular concrete," KS F 2459, 2002.

[27] N. Otsuki, S. Nagataki, and K. Nakashita, "Evaluation of the $\mathrm{AgNO}_{3}$ solution spray method for measurement of chloride penetration into hardened cementitious matrix materials," Construction and Building Materials, vol. 7, no. 4, pp. 195-201, 1993.

[28] F. He, C. Shi, Q. Yuan, C. Chen, and K. Zheng, "AgNO colorimetric methods for measurement of chloride penetration in concrete," Construction and Building Materials, vol. 26, no. 1, pp. 1-8, 2012.

[29] American Society for Testing and Materials, "Half-cell potentials of reinforcing steel in concrete-designation," Book of ASTM Standards C 876-80, Section 4, American Society for Testing and Materials, Philadelphia, Pa, USA, 1980.

[30] M. D. A. Thomas and E. C. Bentz, "Computer program for predicting the service life and life-cycle costs of reinforced concrete exposed to chlorides," Life365 Manual, SFA, 99.84-95, 2002.

[31] J. Glanville and A. Neville, Prediction of Concrete Durability: Proceedings of STATS 21st Anniversary Conference, E \& FN Spon, London, UK, 1st edition, 1995.

[32] J. P. Broomfield, Corrosion of Steel in Concrete: Understanding, Investigation and Repair, 2nd edition, 1997. 

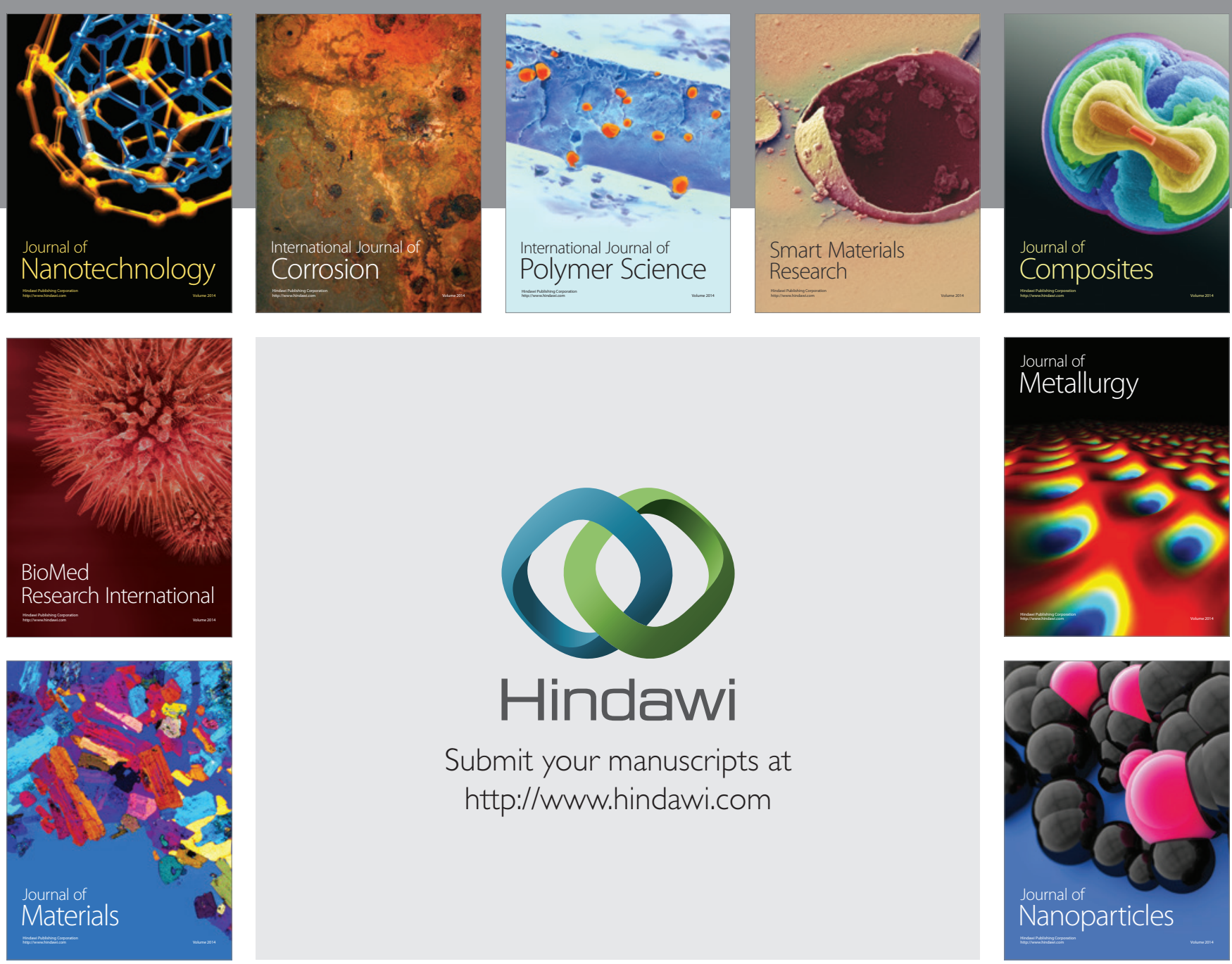

Submit your manuscripts at http://www.hindawi.com
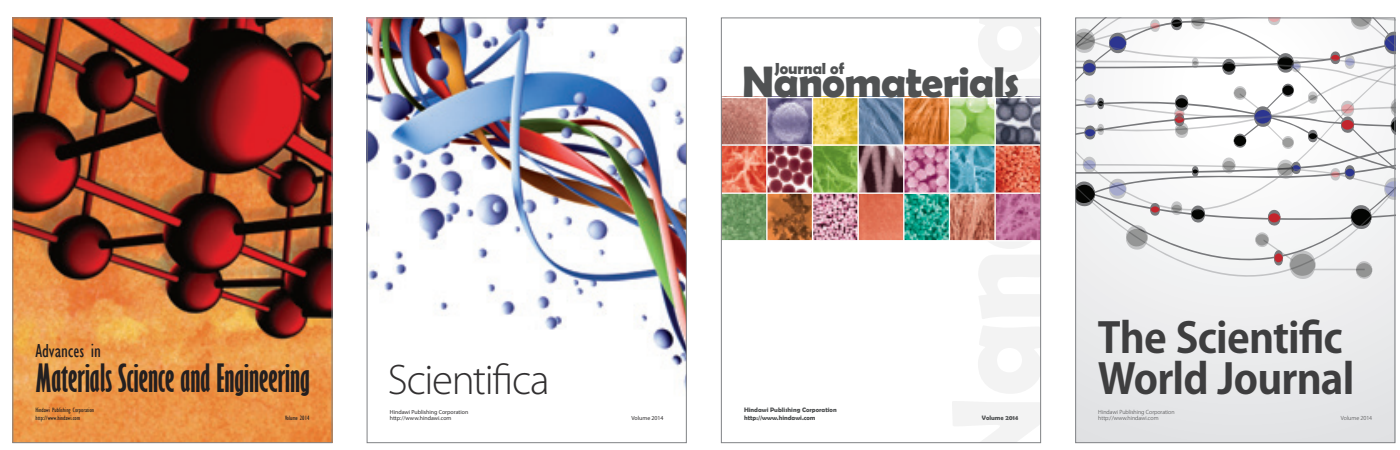

\section{The Scientific World Journal}
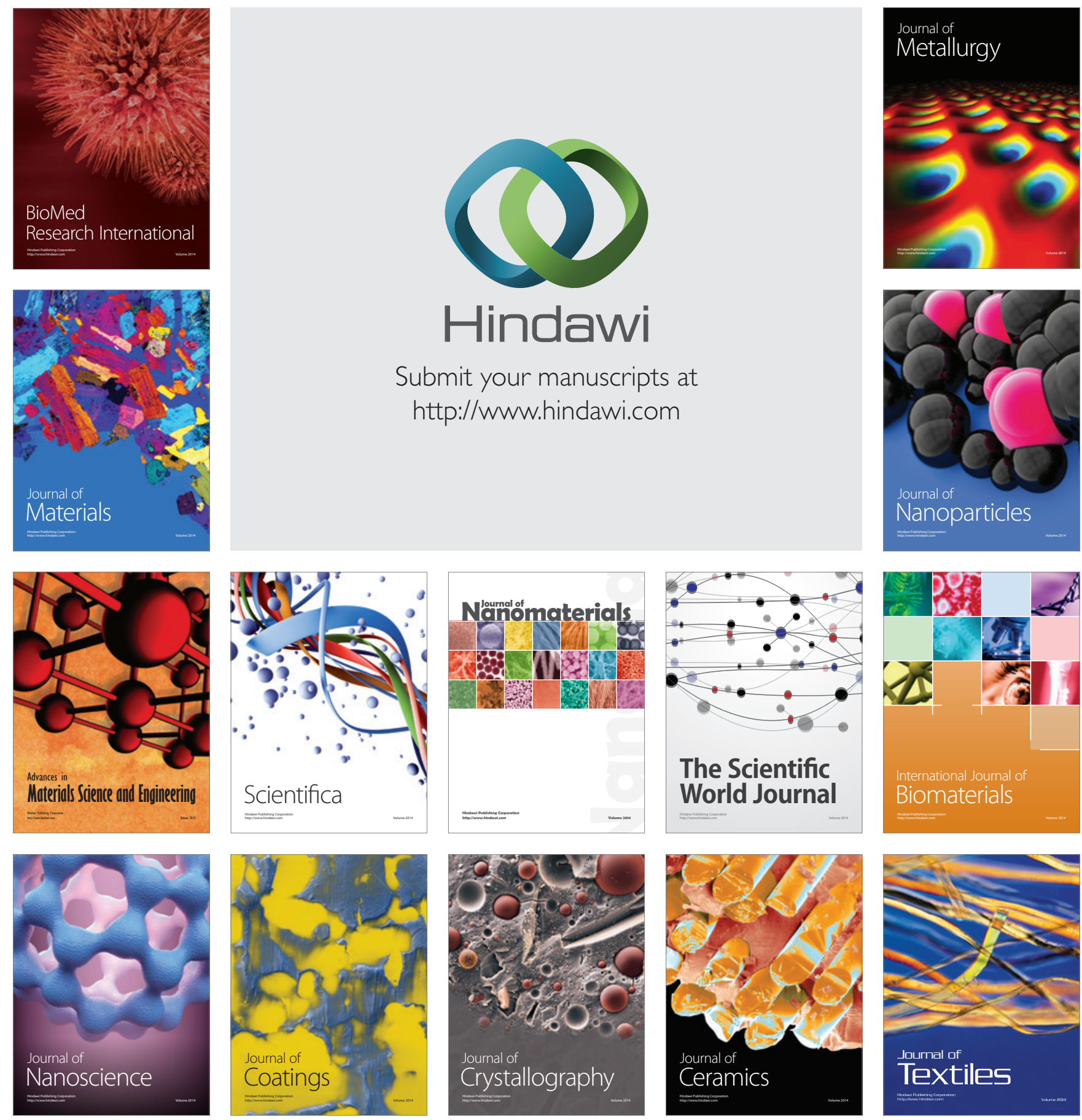